\title{
Effect of Progestagen/PMSG Treatment for Oestrus Synchronization of Tuj Ewes to be Bred after the Natural Breeding Season
}

\author{
O. UCAR ${ }^{1 *}$, M. KAYA², S. YILDIZ ${ }^{2}$, F. ONDER ${ }^{2}$, M. CENESIZ ${ }^{2}$, M. UZUN ${ }^{2}$ \\ Departments of Reproduction and Artificial Insemination ${ }^{1}$ and Physiology ${ }^{2}$, \\ Faculty of Veterinary Medicine, University of Kafkas, Kars, Turkey \\ Received January 5, 2005 \\ Accepted June 6, 2005
}

\begin{abstract}
Ucar O., M. Kaya, S. Yildiz, F. Onder, M. Cenesiz, M. Uzun: Effect of Progestagen/PMSG Treatment for Oestrus Synchronization of Tuj Ewes to be Bred after the Natural Breeding Season. Acta Vet. Brno 74, 2005: 385-393.

The aim of this study was to investigate the effect of pregnant mare serum gonadotrophin (PMSG) and progestagen sponge on oestrus synchronization of Tuj ewes mated after breeding season. Body weights (b.w.) and condition scores (BCS) of seventeen mature fat-tailed Tuj ewes were recorded prior to the experiment and they were divided into two compared groups. All the ewes were treated by $30 \mathrm{mg}$ Chronolone-impregnated intravaginal sponges for 14 days. Ewes in the first group (Group I, $n=9$ ) were then injected with i.m. 600 I.U. PMSG upon sponge withdrawal while others, as control (Group II, $\mathrm{n}=8$ ) received placebo injection only. Ewes were monitored (at $2 \mathrm{~h}$ intervals) for both the signs of oestrus behaviour (classified as attractivity and receptivity) and their durations over the $102 \mathrm{~h}$. Non-return rates were monitored (twice daily) during day 14-21 with the aid of a fertile ram. Lambing rates and litter sizes were recorded following the $150 \pm 5$ days of inseminations (hand-mating). Results showed that oestrus period was significantly prolonged $(P<$ $0.05)$ in Group I. Additionally, a positive significant correlation $\left(P=0.021, \mathrm{R}^{2}=0.345\right)$ was found between BCS in situ and the litter size, regardless of PMSG administration. Furthermore, regardless of the nature of oestrus (induced or natural) in all the ewes, there was a profound effect of BCS per se on the overall litter size $\left(P=0.000, \mathrm{R}^{2}=0.633\right)$. It was significantly higher in ewes that had BCS higher than both $2.0\left(P=0.001, \mathrm{R}^{2}=0.633\right)$ and 2.5 units $\left(P=0.001, \mathrm{R}^{2}=0.654\right)$. In conclusion, PMSG combined with progestagen sponge administration for oestrus synchronization prolonged the duration of oestrus period but with no marked effects on the nonreturn rate, lambing rate or the litter size in Tuj ewes mated after breeding season. During this period, however, body energy reserves appeared to be the major effector of the litter size.
\end{abstract}

Tuj, out-of-season, PMSG, Progesterone, oestrus behaviour, lambing

In general, a number of factors can affect the reproductive activity in sheep. These are: photoperiod (Ortavant et al. 1988), nutrition (Chilliard et al. 1998; Ptaszynska 2001), social interactions (Yildiz et al. 2002ab, 2004), genetics (Ptaszynska 2001), body condition (Yildiz et al. 2002b, 2003b), progestagen (Yildiz et al. 2004), prostaglandin (Yildiz et al. 2003b), melatonin (Haresign 1992), immunisation (Ptaszynska 2001), climate and management (Hafez 1993). For oestrus synchronization in particular, synchrony device, dose of PMSG, breed, week, month and year, and body weight and feeding level may be considered for timing fixed-time inseminations (McMillan 1994). The natural methods (e.g. ram effect) are cheaper but do not result in tight synchronization (Yildiz et al. 2002b) and must be limited to certain conditions (depending on breed and season). By contrast, pharmacological methods (i.e. hormones) are effective in closely synchronizing oestrus in the majority of situations (e.g. out-of-season), that can provide good production after fixed-time insemination (Ptaszynska 2001).

Among the hormonal methods given, progestagen sponge plus PMSG has been routinely available since the early 1960s (Haresign 1992). The technique has been well adapted not only for the induction of oestrus in breeding season (Ozturkler et al. 2003) but also in out-

Address for correspondence:

Dr. Omer Ucar $(D V M, P h D)$

Kafkas University, Faculty of Veterinary Medicine

Department of Reproduction and Artificial Insemination

36040, Kars, Turkey

\author{
Phone: $+904742426801 / 1276$ \\ Fax : +90 4742426853 \\ E-mail: oucar6975@hotmail.com \\ http://www.vfu.cz/acta-vet/actavet.htm
}


of-season (Ptaszynska 2001). By doing so, it is also possible to obtain three lambings within two years. Since the pituitary FSH and LH concentrations are reduced by $50 \%$ during anoestrus season (Thimonier 1981), the dose (particularly that of PMSG, varying from 300 to $600 \mathrm{IU}$ ) needs to be increased to promote consistently high oestrous response leading to higher rates of follicular growth, ovulation and even twinning (Ptaszynska 2001). Indeed, this is also typically relevant for superovulation of ewes in embryo transfer studies (McEvoy et al. 1998).

Furthermore, progestagen has to be combined with PMSG to induce synchronization and/or ovulation in out-of-season (Ak 2002), particularly when the ewes are in deep anoestrus. However, our consideration was that this would not necessarily be the case for those ewes mated just after breeding season. Nevertheless, it was also likely that in lowyielding local sheep breeds (e.g. Tuj or Morkaraman), this situation might be confronted by harsh climate, particularly during long-lasting winter season (November-April). Fat-tailed Tuj sheep (as seasonal breeder, lambing usually in spring) are well adapted to the Caucasian region (with an average altitude of $1,750 \mathrm{~m}$ in our district). They have lower fertility traits than those of Morkaraman (Lacin and Aksoy 2003). Furthermore, ewes may suffer chronically from food shortage in winter that would lead to a poorer reproductive performance (i.e. delay in puberty and ovulation or, even anovulation and early embryonic death) due mainly to depletion of body energy reserves (Chilliard et al. 1998).

Finally, oestrus in the ewe is a less obvious event than in other ruminants (Ptaszynska 2001). Hence, a detailed detection of oestrous stages becomes crucial in this species, particularly in hand-mating or AI. Furthermore, little is known about the nature and duration of oestrous behaviour in Tuj ewes. Therefore, the aim of the present study was to investigate the effect of PMSG combined with intravaginal progestagen sponge on oestrus synchronization of Tuj ewes mated after breeding season.

\section{Materials and Methods}

Animals and experimental protocol

In this study, seventeen clinically healthy fat-tailed Tuj ewes (3-to-6-year-old) were used at the farm of Kafkas University, Kars, Turkey $\left(43^{\circ} \mathrm{E}, 40.5^{\circ} \mathrm{N}\right)$. During normal breeding season (October-December), ewes were kept away from the rams to prevent voluntary mating (see below). In the meantime, however, a teaser ram was introduced to the flock for a short time (one h) on each occasion (once or twice weekly) to determine the presence of oestrus cyclicity (as judged by oestrus behaviour, described below) in season. As expected, the vast majority (13 out of 17) of ewes have actually been 'cycling' (with receptive oestrus signs) 'in' season (by $31^{\text {st }}$ December) while the remaining ewes exhibited only the initial signs of oestrus (attractivity). A 20 day elapsed before they were weighed and condition scores [1-emaciated to 5-obese scale, Ru s s el et al. (1969)] were determined. On day 1 (20 ${ }^{\text {th }}$ January 2003), ewes were divided into two groups as Group I (PMSG; $n=9$ ) and Group II (no PMSG; $n=8)$. All the ewes were then treated by intravaginal sponges impregnated with $30 \mathrm{mg}$ Chronolone (FGA, a progesterone analogue) (Chrono-gest ${ }^{\circledR}$, INTERVET- Istanbul, Turkey). Following sponge removal on day 14 ( $3^{\text {rd }}$ February), 600 IU pregnant mare serum gonadotrophin, PMSG (Chrono ${ }^{\circledR}$-gest/PMSG, INTERVET) was administrated into the pectoral muscle of ewes in Group I while others in Group II received placebo ( $0.9 \%$ sodium chloride) injection only.

The breeding routine of the farm was separation of rams from the flock three months before the commencement of re-unification for mating season $\left(15^{\text {th }}\right.$ November onwards) over three oestrus cycles (until $31^{\text {st }}$ December). For inseminations (hand-mating), three Tuj rams with previously known fertility (over $90 \%$, as of farm records) were used rotationally (changed daily).

\section{Management}

Animals were fed (approximately $1.5 \mathrm{~kg} /$ day/head) twice daily (at $08.00 \mathrm{~h}$ and $16.00 \mathrm{~h}$ ). For feeding, medium quality grass-hay, constituting mainly Gramineae (64.2\%) along with Leguminoseae (22.8\%) and other plant families (13.0\%) (Kay a et al. 2004) was used. Supplementary crushed barley (100 g/day/head) was also provided (Ptaszynska 2001) during the first three weeks, $20^{\text {th }}$ January onwards. In the last period of pregnancy (15 ${ }^{\text {th }}$ May onwards), all the ewes were allowed to graze at pasture of the farm. Ewes had free access to drinking water, as provided in easily accessible metal containers, at all times (in-/outdoors).

During winter season, ewes were housed together in a fenced $(1.5 \mathrm{~m}$ in height $)$ pen $(5 \times 6 \mathrm{~m})$ within one of the main farm buildings. Sufficient poor quality dry hay was provided for bedding. Air conditioning was mainly through the chimney of the roof as well as the door (10-15 $\mathrm{m}$ away from the ewes). The ambient temperature at that 
time (i.e. January-February 2003) ranged from +5.0 to $-22.3{ }^{\circ} \mathrm{C}$, the average being $-7.1^{\circ} \mathrm{C}$ (by Turkish State Meteorological Services, Kars). It was about +5.0 to $15.0{ }^{\circ} \mathrm{C}$ indoor.

Observation of oestrus signs

Following sponge removal, categorisation of behaviours to distinguish between oestrous and non-oestrous ewes was made by a slight modification of the methods of Katz and McDonald (1992). Among the behavioural signs concerned, only the terms of 'attractivity' and 'receptivity' were used for quantification of sexual responsiveness of ewes, as commonly observed herein. Attractivity was used to categorise the ewe's passive ability to stimulate the interest of ram and was usually quantified by measuring his behaviour (the frequency of approach behaviour, smelling or licking of genitalia, flehmen, songs and grinding jaws). Receptivity was evaluated by measuring the movements or postures of ewes ensuring intravaginal insemination by the ram (immobility or standing in response to a mounting ram as most obvious sign, back arching and even leaning or pushing back towards the ram).

Ewes were monitored for both the signs of oestrus behaviour and their durations by the $102 \mathrm{~h}$ (in $2 \mathrm{~h}$ interval). Likewise, the 21 day (as starting from day 14 after sponge removal) non-return rates were determined by observations (twice daily) with the aid of an accompanying fertile ram. During this period, all the oestrous (receptive) ewes were also allowed to mate for determining the actual effect of BCS on the overall litter size in such a small-sized flock studied (17 ewes in total). Lambing rates and litter sizes were recorded following the $150 \pm 5$ days of inseminations.

\section{Statistical analyses}

Data from body weight, BCS, oestrus signs (the onset, end and total durations of attractivity and receptivity), non-return rate, lambing rate and litter size were analysed by Regression analyses or Chi-square test (where appropriate) within the Minitab statistical package (MINITAB Inc, Pennsylvania, USA). For detailed analyses of the relationship between BCS and the 'overall' litter size, i.e. regardless of PMSG administration and/or the nature of oestrus (induced or natural as seen post-induction), arbitrary condition score categories of both 2.0 (Yildiz et al. 2002b) and 2.5 units (Ptaszynska 2001) were also used. Differences were considered statistically significant when $P \leq 0.05$. Data are presented as mean \pm SEM.

\section{Results}

\section{Body weight and BCS}

Body weights (b.w.) and BCS were $56.19 \pm 2.94$ vs $57.21 \pm 2.34 \mathrm{~kg}$ and $2.47 \pm 0.20 v s$ $2.40 \pm 0.12$ units for Group I and II, respectively ( $P>0.05$ both).

\section{Reproductive traits}

Values of the rates of oestrus, non-return and lambing are summarised in Table 1. Apparently, oestrus period was significantly prolonged in Group I (PMSG), as compared to controls (no PMSG). Durations of oestrous (receptive) period of individual ewes are illustrated in Fig. 1.

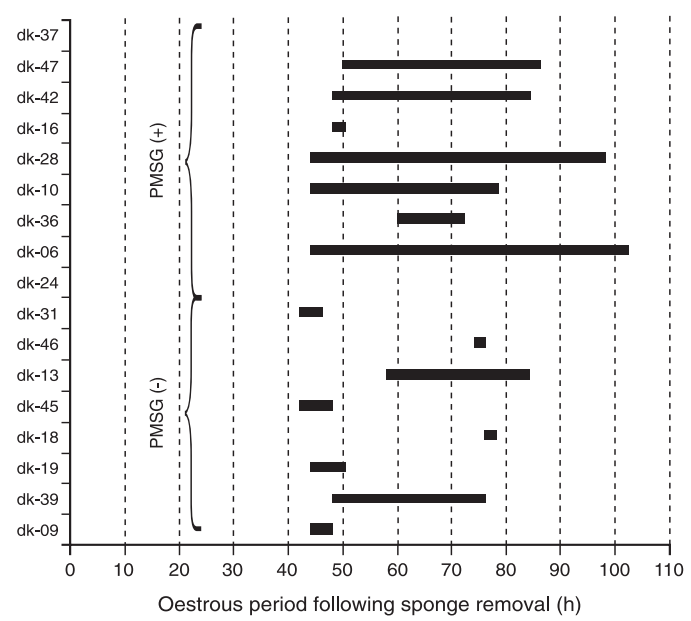

Fig. 1. The durations of oestrous (receptive) period in different PMSG applications (following sponge removal) in Tuj ewes mated after breeding season $(P<0.05)$ 
Table 1. Effect of PMSG administration (following sponge removal) on oestrus synchronization of Tuj ewes mated after breeding season

\begin{tabular}{|c|c|c|c|c|c|c|}
\hline \multirow{2}{*}{\multicolumn{2}{|c|}{ Parameters }} & \multicolumn{2}{|c|}{ Treatment Groups } & \multirow{3}{*}{$\begin{array}{c}\text { F- ratio } \\
1.65 \\
\end{array}$} & \multirow{3}{*}{$\begin{array}{l}P \text { value } \\
0.221\end{array}$} & \multirow{3}{*}{$\begin{array}{l}\text { Significance } \\
\mathrm{NS}\end{array}$} \\
\hline & & \multirow{2}{*}{$\begin{array}{c}\text { I (PMSG) } \\
45.14 \pm 0.74\end{array}$} & \multirow{2}{*}{$\begin{array}{c}\text { II (no PMSG) } \\
48.75 \pm 2.53 \\
\end{array}$} & & & \\
\hline Oestrous & onset & & & & & \\
\hline Attractivity & end & $81.71 \pm 6.61$ & $64.75 \pm 5.54$ & 3.93 & 0.069 & NS \\
\hline (hours) & duration & $36.57^{\mathrm{b}} \pm 7.06$ & $16.00^{\mathrm{a}} \pm 3.63$ & 7.26 & 0.018 & $P<0.05$ \\
\hline \multirow{3}{*}{$\begin{array}{l}\text { Oestrous } \\
\text { Receptivity } \\
\text { (hours) }\end{array}$} & onset & $48.29 \pm 2.16$ & $53.50 \pm 5.04$ & 0.82 & 0.383 & NS \\
\hline & end & $81.43^{b} \pm 6.57$ & $63.25^{\mathrm{a}} \pm 5.84$ & 4.31 & 0.058 & $P \leq 0.05$ \\
\hline & duration & $33.14^{\mathrm{b}} \pm 7.71$ & $9.75^{\mathrm{a}} \pm 3.81$ & 8.03 & 0.014 & $P<0.05$ \\
\hline \multicolumn{2}{|c|}{ Oestrus rate, $\%$} & $77.8 \pm 14.7$ & $100 \pm 0.0$ & 2.02 & 0.176 & $\mathrm{NS}$ \\
\hline \multicolumn{2}{|c|}{ *Non-return rate, $\%$} & $71.4 \pm 18.4$ & $75.0 \pm 16.4$ & 0.02 & 0.887 & NS \\
\hline \multicolumn{2}{|c|}{ *Lambing rate, $\%$} & $57.1 \pm 20.2$ & $50.0 \pm 18.9$ & 0.07 & 0.800 & NS \\
\hline \multicolumn{2}{|l|}{ *Litter size } & $0.71 \pm 0.29$ & $0.50 \pm 0.19$ & 0.41 & 0.533 & NS \\
\hline
\end{tabular}

NS: not significant.

${ }^{\mathrm{a}, \mathrm{b}}$ Means having different superscripts within the same row differ significantly $(P \leq 0.05)$.

*Values were calculated by considering the ewes showing oestrus (induced by sponge and/or PMSG) only.

Additionally, irrespective of PMSG administration, there was a significant effect $(P=$ $0.021, \mathrm{R}^{2}=0.345$ ) of BCS (positive in situ) on the litter size, but with no such effects on the rates of induced oestrus (up to $102 \mathrm{~h}$ following sponge removal), non-return or lambing. Nevertheless, when the 'overall' lambing rates (including those inseminations between day 14-21 post-induction as well) were considered, there was a profound effect of BCS (positive in situ) on the overall litter size for both BCS categories of 2.0 and 2.5 units (Table 2). In other words, the overall litter size of individual ewes increased as the BCS increased, within the range of 1.5 to 3.5 units (Fig. 2).

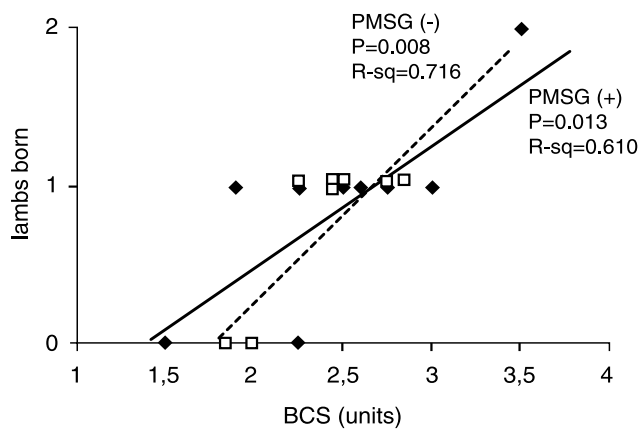

$(\diamond)$ PMSG (+); ( $\square$ ) PMSG (-), Linear regression lines best described the data (points overlapping detached slightly) $(\mathrm{n}=17)$

Fig. 2. The relationship between BCS and the overall litter size in different PMSG applications (following sponge removal) in Tuj ewes mated after breeding season $(P=0.000)$

\section{Discussion}

Findings showed that combining the PMSG administration with progestagen sponge prolonged the oestrus period in Tuj ewes mated after breeding season. Additionally, regardless of PMSG administration, there was a marked effect of BCS (positive in situ) on the litter size.

Ptaszynska (2001) noted that following sponge and PMSG administration, the ewes begin to show behavioural signs of (attractive) oestrus at approximately $24 \mathrm{~h}$, but most will 
Table 2. Relationship between BCS and the overall litter size of Tuj ewes mated after breeding season $\left(P=0.000, \mathrm{R}^{2}=0.633\right)$

\begin{tabular}{|c|c|c|c|c|c|c|}
\hline \multicolumn{2}{|c|}{ Condition score category, units } & Ewes (n) & Mean BCS & Litter size & $\mathrm{R}^{2}$ & $P$ value \\
\hline \multirow{2}{*}{ BCS- 2.0} & $>2.0$ & 13 & $2.63 \pm 0.10$ & $1.00^{\mathrm{b}} \pm 0.11$ & \multirow{2}{*}{0.633} & \multirow{2}{*}{0.001} \\
\hline & $\leq 2.0$ & 4 & $1.81 \pm 0.11$ & $0.25^{\mathrm{a}} \pm 0.25$ & & \\
\hline \multirow{2}{*}{ BCS- 2.5} & $>2.5$ & 6 & $2.91 \pm 0.13$ & $1.17^{b} \pm 0.17$ & \multirow{2}{*}{0.654} & \multirow{2}{*}{0.001} \\
\hline & $\leq 2.5$ & 11 & $2.18 \pm 0.10$ & $0.64^{a} \pm 0.15$ & & \\
\hline
\end{tabular}

a,b Means having different superscripts within the same BCS category row differ significantly $(P<0.05)$.

not be in (receptive) oestrus until the 36-48 h. Additionally, Robin s on (1988) reported that the onset of oestrus in PMSG-administrated ewes has a normal distribution, with a range of $24 \mathrm{~h}$, centred around a mean of $33 \mathrm{~h}$. Furthermore, McMillan (1994) reviewing the interval to the onset of oestrus in synchronized ewes in some detail, considered that 'during' the breeding season, ewes synchronized by progesterone-impregnated controlled internal drug release devices $\left(\mathrm{CIDR}^{\circledR}\right)$ together with PMSG at doses of 0,400 and $800 \mathrm{IU}$ had similar mean intervals to the onset of oestrus ( 33 vs 31 vs $30 \mathrm{~h}$, resp.). By contrast, as compared to controls, treatment with 400 or 800 IU PMSG 'outside' the breeding season decreased the interval (50 vs 39 vs $37 \mathrm{~h}$, resp.) as well as the variation. $\mathrm{CIDR}^{\circledR}$-treated ewes had 10-24 h shorter mean interval as compared to MAP or FGA (as used herein, too) depending on feeding level. Our findings, with PMSG administration, are similar to those reports given above 'during' the breeding season. However, present results may further imply that PMSG favoured, at least to some extent, the follicular growth (see below). Additionally, Lunstra and Christen s on (1981a) observed significant declines in ovulation and conception rates as well as ram marking activity particularly when the onset of oestrus occurred $72 \mathrm{~h}$ or more after PMSG administration during anoestrous season. Furthermore, their reduced lambing rates reported may be due to an increased asynchrony of reproductive events in the ewe synchronized outof-season, as the interval increased. However, this effect was not obvious herein. Clearly, the little difference of the interval, as being slightly shorter in PMSG-treated (48.3 h) as compared to control ewes $(53.5 \mathrm{~h})$, would have been even greater if the experimental animals had been used in deep anoestrus (e.g. in summer).

Furthermore, the normal oestrus period in breeding season is about $36 \mathrm{~h}$ on average, but it may vary, between 18 and $72 \mathrm{~h}$, with age, breed and season (P tas zynska 2001). Similar results were found in PMSG-treated ewes, as compared to controls (33.1 vs $9.8 \mathrm{~h}$, resp.). This may indicate favourable effect of PMSG in prolonging the oestrus period after breeding season. A prolonged oestrus presumably resulted from elevated concentrations of circulating oestrogen (produced by enlarged follicles) that would ensure subsequent LH peak to take place (Ptaszynska 2001; Yildiz et al. 2004). This might increase the chance of a higher rate of ovulation and thus successful fertilisation. In one hand, a prolonged oestrus also sustains ram libido longer. This can facilitate detection of oestrous ewes and thus increase the numbers of fertile mating (or AI) per ewe (Mc Millan 1994). On the other hand, AI may be an alternative to overcome the likelihood of ram subfertility because of lower semen quality out-of-season(Lunstra and Christen s on 1981b, Thimonier 1981, Ucar and Parkinson 2003).

One of the ewes (db-24; having BCS of 1.5 units, as the lowest of all) in PMSG group showed no signs of oestrus at all throughout the study. Undernutrition (lower BCS) increases the incidence of anoestrus (Dunn and Kaltenbach 1980). Likewise, Ortavant et al. (1988) considering the interaction between reproduction and seasonal factors (i.e. fluctuations of food availability and the level of body reserves), reported that it may prevent emaciated females from risks linked with the high nutritional demand of subsequent 
pregnancy and lactation, which may impair the survival of both mother and the offspring. Indeed, BCS in situ appeared to be positively affecting the litter size. Hence, it would also be logical to consider further the effect of BCS on the 'overall' litter size. There was a profound effect of BCS per se on the overall litter size such that it increased as the BCS increased (1.5 to 3.5 units) both in PMSG and in control groups, being more important in the latter. This may indicate that the favourable effect of BCS in situ on the litter size became even much stronger in control group. These might give some clues to the synergetic effects of PMSG and BCS on the lambing performance. Additionally, ewes having a BCS less or equal to 2.5 units had a markedly lower litter size than in those having higher units. This was also the case for BCS less or equal to 2.0 units, as confirming well our previous findings with plasma LH (Yildiz et al. 2002b). By contrast, one of the ewes (db-42) having BCS of 3.5 units (the highest of all) in PMSG group had twinning. Ptaszynska (2001) noted that in general, ewes respond optimally to flushing when in medium BCS (2.5-3.5) rather than when exclusively thin or fat. Likewise, Al-Sabbagh et al. (1995) concluded that, within this range, $\mathrm{BCS}$ is not an important factor in affecting total weight of lamb born, lamb mortality, or total weight of lamb weaned. Hence, BCS of 2.5 units is considered critical (as threshold) to affect reproductive performance in sheep breeding. Apparently, better BCS at mating can usually lead to a higher conception rate (Ptaszynska 2001). Indeed, Alabart et al. (2003) observed that BCS contribute to a higher prolificacy (better when BCS was higher, up to 3.5, than 2.9) in embryo donors superovulated with FSH. Likewise, Tho mas et al. (1987) found that mating BCS of $3.2 v s 2.9$ resulted in a greater number of ovulations (1.99 vs 1.74), but little difference in the litter size. However, higher differences between the BCS of those ewes would have led dramatic differences in the litter size. In cattle, Y a mada et al. (2003) reported that the ovarian cyclicity and conception rates of cows having a BCS of 2.75-3.25 were higher than in those having a BCS less or equal to 2.5. Likewise, Klindworth et al. (2001) found that conception rate was lower for cows having a BCS higher than 3.25 and less than 2.75 than for those having a BCS of 3.0. However, there are also some controversial reports in cattle (Drew et al. 1982) that would need further consideration. Additionally, in the scarcity of such data in the literature, it becomes relevant to discuss further the actual effect of BCS in sheep reproduction in a broader sense.

Grimard et al. (1997) concluded that follicular growth, oestradiol secretion, ovulation and pregnancy rate after synchronization (along with PMSG) are related to mobilisation of energy stores before treatment in cows having the same BCS. Additionally, Randel (1990) considered that the lack of ovarian activity in underfed cows appears to be due to a suppression of the pulsatile release of LH. Indeed, our previous results (Yildiz et al. $2002 \mathrm{~b}$ ) showed that ewes having a BCS less or equal to 2.0 units had significantly lower LH pulse frequencies, as also reported previously in sheep (Robinson 1990) and in cattle (Yildiz et al. 1997). Likewise, Wright et al. (1992) reported that the fatter cows (2.79vs 1.97) had higher levels of LH patterns. Chilliard et al. (2000) found that LH pulsatility is more sensitive to undernutrition when ewes contain less than $150-200 \mathrm{~g}$ fat $/ \mathrm{kg} \mathrm{b}$.w. They also considered that the fat depot of the tail of some ovine breeds seems to play a particular role in adaptation to undernutrition. Therefore, Yildiz et al. (2002b) concluded that in fattailed sheep breeds (Tuj), differing in adipose tissue deposition and mobilisation, LH pulse frequency is well correlated with BCS. Furthermore, Y ild iz et al. (2003b) also reported that BCS is positively correlated to the timing of LH surge. Hence, Yildiz et al. (2003a) considered that the link between BCS and hypothalamus, where GnRH secretion is initiated, appear to include leptin secretion from the adipose tissue since it informs the hypothalamus about the sufficiency of energy stores for the initiation of reproductive activity (Blache et al. 2000; Chilliard et al. 2001). The latter workers also reported that plasma leptin was correlated positively with body fatness and energy balance. Collectively, body energy 
reserves, rather than sponge and/or PMSG administrations, appear to be the major effector of the litter size in sheep. Therefore, future studies are required to highlight the relationships between BCS, plasma LH, and/or leptin as well as their effects on reproduction in this species.

Overall, present findings indicate that oestrus synchronization by progesterone alone or, preferably, along with PMSG may be used effectively in Tuj ewes mated after breeding season depending on BCS. This is also in line with the recommendation that when ewes are being synchronized for fixed-time AI using progesterone-based programmes, PMSG should always be used to reduce variation in the timing of ovulation between individuals (Lunstra and Christenson 1981ab; Ptaszynska 2001) and thus to increase the chance of successful fertilisation (McMillan 1994), especially in deep anoestrous season. However, future studies using a higher number of ewes in different reproductive stages are needed to elucidate the actual effects of PMSG and BCS for oestrus synchronization in various sheep breeds. In conclusion, PMSG combined with progestagen sponge administration for oestrus synchronization prolonged the duration of oestrus period but with no marked effects on the non-return rate, lambing rate or the litter size in Tuj ewes mated after breeding season. During this period, however, body energy reserves appeared to be the major effector of the litter size.

\section{Účinek ošetření progestagenem PMSG na synchronizaci říje u bahnic plemene Tuj zapuštěných po připouštěcí sezóně}

Cílem studie bylo zjistit účinek sérového gonadotropinu březích klisen (PMSG) a progestagenové houbičky na synchronizaci řije bahnic plemene Tuj zapuštěných po připouštěcí sezóně. Před pokusem byla zaznamenána hmotnost a BCS u 17ti dospělých tlustoocasých bahnic. Ovce byly rozděleny do dvou skupin. V̌̌em bahnicím byly na 14 dní intravaginálně aplikovány houbičky impregnované 30 mg Chronolonu. Bahnicím první skupiny (skupina $1, \mathrm{n}=9$ ) bylo po vyjmutí houbičky i.m. aplikováno 600 I.U. PMSG zatímco druhé, kontrolní skupině (skupina 2, $\mathrm{n}=8$ ) byla aplikována jen placebo injekce. U bahnic byla během následujících 102 hodin ve 2-h intervalech zjištována přítomnost behaviorálních př́iznaků říje (klasifikovaných jako atraktivita a vnímavost) a doba jejich trvání. Množství nezabřezlých bylo zjištováno dvakrát denně během 14.21. dne pomocí plodného berana. V údobí $150 \pm 5$ dní po inseminacích (zapuštění z ruky) byla zaznamenána početnost a velikost (hmotnost) vrhů. Výsledky ukázaly, že doba říje byla u skupiny 1 signifikantně prodloužena $(P<0.05)$. Navíc byl zjištěn pozitivní vztah mezi BCS in situ a velikostí (hmotností) vrhu $(P=0.021, \mathrm{R} 2=0.345)$ bez ohledu na aplikaci PMS. Dále zde byl bez ohledu na povahu říje bahnic (indukované nebo přirozené) velký vliv BCS per se na celkovou velikost vrhu $(P=0.000, \mathrm{R} 2=0.633)$. Ten byl signifikantně větší u bahnic, které měly BCS vyšší než $2,0(P=0.001, \mathrm{R} 2=$ $0.633)$ a 2,5 $(P=0.001, \mathrm{R} 2=0.654)$. Z práce vyplývá, že PMSG kombinovaný s aplikací progestagenové houbičky pro synchronizaci říje prodloužil její trvání, ale bez výrazného ovlivnění počtu nezabřezlých bahnic, početnosti a velikosti (hmotnosti) vrhu. Nicméně se ukázalo, že v tomto období mají největší vliv na velikost vrhu zásoby energie matky.

\section{References}

AK, K 2002: Reproduction and artificial insemination in sheep (in Turkish). In: ILERI, I.K., AK, K., PABUCCUOGLU, S., USTA, S.: Evcil Hayvanlarda Reproduksiyon ve Sun'i Tohumlama. Istanbul Universitesi Veteriner Fakultesi Yayini, Ders Notu No: 133. Istanbul, Turkey. pp 189-205

ALABART, JL, FOLCH, J, FERNANDEZ-ARIAS, A, RAMON, JP, GARBAYO, JM, COCERO, MJ 2003: Screening of some variables influencing the results of embryo transfer in the ewe. Part II: two-day-old embryos. Theriogenology 59: 1345-1356 
AL-SABBAGH, TA, SWANSON, LV, THOMPSON, JM 1995: The effect of ewe body condition at lambing on colostral immunoglobulin G concentration and lamb performance. J Anim Sci 73: 2860-2864

BLACHE, D, TELLAM, RL, CHAGAS, LM, BLACKBERRY, MA, VERCOE, PE, MARTIN, GB 2000: Level of nutrition affects leptin concentrations in plasma and cerebrospinal fluid in sheep. J Endocrinol 165: 625-637

CHILLIARD, Y, BONNET, M, DELAVAUD, C, FAULCONNIER, Y, LEROUX, C, DJIANE, J, BOCQUIER, F 2001: Leptin in ruminants. Gene expression in adipose tissue and mammary gland, and regulation of plasma concentration. Dom Anim Endocrinol 21: 271-295

CHILLIARD, Y, FERLAY, A, FAULCONNIER, Y, BONNET, M, ROUEL, J, BOCQUIER, F 2000: Adipose tissue metabolism and its role in adaptations to undernutrition in ruminants. Proc Nutr Soc 59: 127-134

CHILLIARD, Y, BOCQUIER, F, DOREAU, M 1998: Digestive and metabolic adaptations of ruminants to undernutrition, and consequences on reproduction. Reprod Nutr Dev 38: 131-152

DREW, SB, GOULD, CM, DAWSON, PL, ALTMAN, JF 1982: Effect of progesterone treatment on the calvingto-conception interval of Friesian dairy cows. Vet Rec 111: 103-106

DUNN, TG, KALTENBACH, CC 1980: Nutrition and the postpartum interval of the ewe, sow and cow. J Anim Sci 51 Suppl 2: 29-39

GRIMARD, B, HUMBLOT, P, MIALOT, JP, JEANGUYOT, N, SAUVANT, D, THIBIER, M 1997: Absence of response to oestrus induction and synchronization treatment is related to lipid mobilization in suckled beef cows. Reprod Nutr Dev 37: 129-140

HAFEZ, ESE 1993: Reproductive behaviour. In: HAFEZ E.S.E.: Reproduction in farm animals, $6^{\text {th }}$ Edn. Lea and Febiger, Philadelphia, USA, pp. 237-257

HARESIGN, W 1992: Manipulation of reproduction in sheep. J Reprod Fert Suppl 45: 127-139

KATZ, LS, MCDONALD, TJ 1992: Sexual behaviour of farm animals. Theriogenology 38: 239-253

KAYA, I, ONCUER, A, UNAL, Y, YILDIZ, S 2004: Nutritive value of pastures in Kars district I. Botanical and nutrient composition at different stages of maturity. Turk J Vet Anim Sci 28: 275-280

KLINDWORTH, HP, HOEDEMAKER, M, BURFEINDT D, HEILKENBRINKER, T 2001: Synchronization of ovulation (OVSYNCH) in high-producing dairy cattle herds. I. Fertility parameters, body condition score and plasma progesterone concentration (in German). Dtsch Tierarztl Wochenschr 108: 11-19

LACIN, E, AKSOY, AR 2003: Comparison of reproductive performance of Morkaraman and Tushin ewes in Kars region (in Turkish). Kafkas Univ Vet Med J 9: 5-7

LUNSTRA, DD, CHRISTENSON RK 1981a: Synchronization of ewes during anestrus: influence of time of year and interval to onset of estrus on conception rate. J Anim Sci 53: 448-457

LUNSTRA, DD, CHRISTENSON RK 1981b: Fertilization and embryonic survival in ewes synchronized with exogenous hormones during the anestrous and estrous seasons. J Anim Sci 53: 458-466

MCEVOY, TG, ROBINSON, JJ, AITKEN, RP, ROBERTSON, IS 1998: Melatonin treatment of embryo donor and recipient ewes during anestrus affects their endocrine status, but not ovulation rate, embryo survival or pregnancy. Theriogenology 49: 943-955

MCMILLAN, WH 1994: Timing fixed-time inseminations in ewes: Some new aspects. Proc NZ Soc Anim Prod 54: 45-49

ORTAVANT, R, BOCQUIER, F, PELLETIER, J, THIMONIER J, VOLLAND-NAIL, P 1988: Seasonality of reproduction in sheep and its control by photoperiod. Austr J Biol Sci 41: 69-85

OZTURKLER, Y, COLAK, A, BAYKAL, A, GUVEN, B 2003: Combined effect of a prostaglandin analogue and a progestagen treatment for 5 days on oestrus synchronisation in Tushin ewes. Indian Vet J 80: 917-920

PTASZYNSKA, M 2001: Ovine reproduction. In: PTASZYNSKA, M.: Compendium of animal reproduction. $6^{\text {th }}$ Revised edn. Intervet Int bv (The Netherlands). pp 125-147

RANDEL, RD 1990: Nutrition and postpartum rebreeding in cattle. J Anim Sci 68: 853-862

ROBINSON, JJ 1990: Nutrition in the reproduction of farm animals. Nutr Res Rev 3: 253-276

ROBINSON, TJ 1988: Controlled sheep breeding: update 1980-1985. Aust J Biol Sci 41: 1-13

RUSSEL, AJF, DONEY, JM, GUNN, RG 1969: Subjective assessment of body fat in live sheep. J Agric Sci (Cambridge) 74: 451-454

THIMONIER, J 1981: Control of seasonal reproduction in sheep and goats by light and hormones. J Reprod Fertil Suppl 30: $33-45$

THOMAS, DL, THOMFORD, PJ, CRICKMAN, JG, COBB, AR, DZIUK, PJ 1987: Effects of plane of nutrition and phenobarbital during the pre-mating period on reproduction in ewes fed differentially during the summer and mated in the fall. J Anim Sci 64: 1144-1152

UCAR, O, PARKINSON, TJ 2003: In vitro induction of the acrosome reaction in ovine spermatozoa by calcium ionophore A23187. Acta Vet Hung 51: 103-109

WRIGHT, IA, RHIND, SM, SMITH, AJ, WHYTE, TK 1992: Effects of body condition and estradiol on luteinizing hormone secretion in post-partum beef cows. Domest Anim Endocrinol 9: 305-312

YAMADA, K, NAKAO, T, ISOBE, N 2003: Effects of body condition score in cows peripartum on the onset of postpartum ovarian cyclicity and conception rates after ovulation synchronization/fixed-time artificial insemination. J Reprod Dev 49: 381-388

YILDIZ, S, UZUN, M, KAYA, M, UCAR, O, CENESIZ, M 2004: Effects of rams and luteal or follicular phase ewes on preovulatory LH surge characteristics in ewes. Turk J Vet Anim Sci, 28: 669-673 
YILDIZ, S, BLACHE, D, CELEBI, F, KAYA, I, SAATCI, M, CENESIZ, M, GUVEN, B 2003a: Effects of shortterm high carbohydrate or fat intakes on leptin, growth hormone and luteinizing hormone secretions in prepubertal fat-tailed Tuj lambs. Reprod Domest Anim 38: 182-186

YILDIZ, S, SAATCI, M, UZUN, M, GUVEN, B 2003b: Effects of ram introduction after the second prostaglandin F2 alpha injection on day 11 on the LH surge characteristics in fat-tailed ewes. Reprod Dom Anim 38: 54-57

YILDIZ, S, GUVEN, B, COLAK, A, UZUN, M 2002a: Progesterone profiles of fat-tailed Tuj ewes following tactile and visual separation of rams at the beginning of breeding season. J Vet Med A 49: 132-136

YILDIZ, S, UZUN, M, CENESIZ, M, UCAR, O, KAYA, M, ONDER, F 2002b: Effects of sexually activated rams or ewes on pulsatile LH secretion in anoestrous sheep. Acta Vet Brno 71: 297-302

YILDIZ, S, SINCLAIR, KD, GEBBIE, FE, HUTCHINSON, JSM, BROADBENT, PJ 1997: The relationship between LH pulse frequency, ovarian folliculogenesis and body condition in post-partum beef cows. J Reprod Fertil, Abstract series No: 19: 152 